\title{
Comparing Work-Life Conflict in Europe: Evidence from the European Social Survey
}

\author{
Frances McGinnity $\cdot$ Christopher T. Whelan
}

Accepted: 21 December 2008/Published online: 6 February 2009

(C) Springer Science+Business Media B.V. 2009

\section{Introduction}

This special issue compares work-life conflict in Europe using the European Social Survey: this introductory article attempts to provide a synthesis of the issue. It sets the scene for the papers that follow, discussing the concept of work-life conflict and its measurement. It considers previous research and approaches, before considering the themes of individual articles. All the articles, and this editorial essay, draw on the valuable insights of an excellent team of reviewers. ${ }^{1}$

Reconciling work and family commitments has become a critical issue in European societies, against a backdrop of globalization and rapid technological change, an ageing population and concerns over labour market participation and falling fertility (OECD 2001; Jacobs and Gerson 2004). Within the European union the 'reconciliation of work and family' has become a core concern for policy and encouraged national-level debate and policy intervention. As an indicator of quality of life, work-life balance has gained both academic and policy currency. Work-life conflict has a potentially detrimental impact on personal effectiveness, marital relations, child-parent relationships and even child development (Gornick and Meyers 2003). It has also been linked to decreased job and life satisfaction as well as stress-related outcomes including psychological strain, anxiety and depression, exhaustion and alcohol abuse (Allen et al. 2000).

The increased focus on work-life conflict is associated not only with a greater emphasis on quality of life but also with emerging challenges to long-standing welfare state arrangements. The increasing salience of human capital, adaptability and flexibility has

${ }^{1}$ A list of reviewers' names is provided in Appendix 2, in recognition of their contribution.

F. McGinnity ( $\bowtie)$

Economic and Social Research Institute, Whitaker Square, Sir John Rogerson's Quay, Dublin 2, Ireland

e-mail: Fran.McGinnity@esri.ie

C. T. Whelan

UCD School of Sociology, Newman Building, University College Dublin, Belfield, Dublin 4, Ireland e-mail: Chris.Whelan@ucd.ie 
focused attention on the need to reconcile investment in children with sustained labour force participation and human capital accumulation over the life cycle (Bovenberg 2007). Attention has increasingly focused on the distinction between 'old' and 'new' social risks. Taylor-Gooby (2004) notes that the latter are associated with care responsibilities primarily at the stage of family building, and extend demand for state intervention into areas of life that had been seen as private from an old risks perspective.

Under the traditional male breadwinner model competing demands in the employment and family sphere were managed by a division of labour between the sexes, whereby men were primarily responsible for paid employment and women were primarily responsible for caring. The growth in female employment and dual-earner families, the rise in lone parent families and the ageing population mean that an increasing number of EU citizens now have to combine both employment roles and caring responsibilities in relation to both children and older people. Currently, most fathers are employed full-time and most mothers work for pay: many parents are struggling to find employment arrangements that are economically viable, beneficial to children, and equitable (Gornick 2007). Increased time pressures and strains are also thought to arise within the workplace. While the direction of long-term trends in the hours of work is debated, there is considerable evidence of increased work intensity throughout Europe (Thirion et al. 2007).

Yet while many EU countries share common features, there are also differences. Common problems generate hybrid responses conditioned by pre-existing institutional arrangements but shaped also by the kind of learning experiences that the EU seeks to promote through the Open method of coordination (Ferrera and Rhodes 2000; Surender 2004). The shape and nature of employment is different: for example in some countries part-time work is common, in others, it represents a small proportion of employment. In some countries, mothers' and fathers' employment rates are rather similar, in others they vary enormously. Policies vary too: for example the way in which working patterns are structured by regulation and employers_-working hours, annual leave entitlement, availability of flexible working arrangements. Family leave rights and benefits and support for childcare, as well as the overall tax-benefit regime also vary (Gornick 2007). Gender role attitudes differ, particularly regarding support for maternal employment (Lueck 2006). Many countries in the newly enlarged EU had decades of communist family and employment policies, in contrast to the democracies, albeit in differing forms, of the West. All of these factors may influence individuals' ability to combine work and non-work demands.

The existence of so much variability, against a backdrop of commonality, motivates this special issue. In this collection of articles we wish to investigate if and how work-life conflict varies cross-nationally. In evaluating the conclusions of individual articles it is necessary to take into account that in commenting on cross-country differences some authors wish to control for factors that others choose to include in their estimates of country effects. The precise meaning of country effects is thus dependent on the specific questions that authors have sought to address. Overall our focus is less on variation in levels of work-life conflict but rather on the manner in which processes and factors associated with work-life conflict vary across countries. To investigate this question, all the articles use a high-quality data source with identical indicators for each country, the European social survey (ESS), which has a specially designed module on work-life balance and is cross-nationally representative. This special module on family, work and well-being (2004) is particularly well suited to examining country variation in work-family balance in a wide range of countries, for many of whom this topic has not been previously investigated. Articles focus on a range of themes and select varying numbers of countries for the 
analysis but they are all comparative, and all use ESS data. The special issue offers readers new insights into the interface between work and family life in the new European union, touching on recent changes in forms of employment and family forms, changes in work intensity, upskilling, debates on time poverty and busyness, on social class, on social comparison, job allocation, gender and motherhood wage penalties and gender differences in the distribution of paid and unpaid labour.

\section{Work Life Conflict: Concepts and Measurement}

Work-life balance is the term which has gained popularity, and is in many ways a favourite formula in today's literature about the (post) modern working world, though as some authors note, a concern with the interaction between paid work and other domains of life is not new (Lewis et al. 2007). While the terms are sometimes used interchangeably, we prefer work-life conflict to work-life balance, as it draws attention to the challenges, tensions and trade-offs which may be associated with combining work and family life. The focus is on the trade-offs and the central idea is that meeting demands in one domain makes it difficult to meet obligations in the other (Felstead et al. 2002; Steiber 2007; for a discussion of definitions see Greenhaus and Singh 2003). Such conflict can take two forms: from work to family and from family to work, although work tends to affect family more than vice versa (Byron 2005). This special issue incorporates concern with both work-tolife and life-to-work issues but with a somewhat greater emphasis on the former. Some authors limit the focus to 'work-family conflict', considering just couples or parents, some consider all employees, and broaden the concept to consider conflict with other aspects of life, not just family or partner, for which the most appropriate term is 'work-to-life'. ${ }^{2}$ One appeal of the concept in research terms is that it allows a wider understanding of non-work concerns to be encompassed in employment research.

The concept of work-life conflict is not without limitations. The term has been criticised as being a fashionable term with a short shelf-life (Hildebrandt and Littig 2006). Others argue that the concept assumes clearly defined spheres of work and life, while the distinction between work and non-work activities is not unproblematic, as much time-use research shows (Hildebrandt and Littig 2006; Gershuny 2000). In employing the concept it is important to keep in mind the limits to our understanding posed by the fact that work-life conflict is observed only for those in employment, and those with very high work-life conflict may have exited the labour market. A final limitation is that the focus here is on current work-family tensions and there may well be other current and future 'costs' that cannot be addressed within this issue. For instance, some households may have minimised conflict at the cost of postponed or limited family formation. Similarly there may be longer term labour market costs of reconciling work and family life, for instance with respect to wages and career development.

Work-life conflict has been measured in a number of ways. Some authors take 'objective' indicators of conflict by assuming, say, that part-time work is an indicator of low work-life conflict (e.g., McGinnity and McManus 2007 and other articles in this special issue) or they assume that high paid work hours are inimical to work-life balance

\footnotetext{
2 As MacInnes (2006) notes, there is continual tension in both the academic literature and policy discussions as to whether the work-life conflict refers to just parents (hence 'work-family conflict') or to all adults; whether 'life' refers to caring, or leisure or both (see MacInnes 2006, for a discussion).
} 
(Gornick and Meyers 2003). Writers from a time-use perspective usually add paid and unpaid work hours (e.g., Bittman 2004).

A more common approach to work-life conflict focuses on the assessment of the individual. This perspective assumes that work-life conflict is primarily subjective, and allows for variability in responses to the objective conditions arising from difference in resources, energy, motivations and expectations. The respondent's definition of the situation comes to play an important role. Some papers in this issue use a subjective index of work-life conflict as the dependent variable (Russell and Gallie; McGinnity and Calvert; Kasearu) or single items (Steiber); others use a broader measure of life satisfaction (Boye) or a series of measures combining both (Scherer).

Yet a crucial point to recognise about subjective indicators of work-life balance or life satisfaction is that they reflect the interaction between people's situation and their expectations (Fahey et al. 2003). Expectations may adapt to the situation. Objective indicators (i.e., poverty) often do not correlate well with subjective counterparts (i.e., life satisfaction). Recent research looks at liveability and comparison (reference group) theories, notions of threshold effects, or the impact of relative versus absolute differences in objective variables (Veenhoven 1996). People evaluate their objective standards by comparing their actual situation to reference points. This can be their past situation, the situation of people similar to themselves or their notion of what is reasonable or practical in current circumstances. That said, establishing reference groups can be very challenging, as discussed in a paper by Katarina Boye in this volume.

We use both subjective and objective indicators, adopting a sociological perspective that focusing entirely on one or the other would miss an important part of the reality we are trying to capture (Fahey et al. 2003). Our focus is on the relationship between reported satisfaction/work-life balance and resources, conditions and workload, and the factors mediating that relationship.

\section{Research on Work-Life Conflict}

Recent research on the topic has adopted a number of different approaches. Studies have focused on theoretical issues (Guest 2002; Voydanoff 2004), single country studies (Fagnani and Letablier 2004; Kinnunen and Mauno 2004), middle class couples (Schneider and Waite 2005); occupational groups (Greenhaus et al. 2003) and organisational and sectoral case studies (Perrons 2003; White et al. 2003). Organisational, occupational and sectoral case studies give depth and insight into processes and practices at the firm level, but findings may be sensitive to the choice of cases. This is also true of Schneider and Waite's (2005) innovative study of work-life balance among middle class couples. It is rich in data sources and methods but limited to dual-earning middle class US couples. It is difficult to generalise from single country studies, as they do nothing to establish whether the processes are generalisable across countries: post-hoc comparisons are affected by differences in approach, samples and measurement.

Cross-national comparative research on the level and determinants of work-life conflict is in its infancy. The studies that do exist have stressed the importance of considering the full range of mediating institutional-level factors (Crompton and Lyonette 2006; Scherer and Steiber 2007). These include welfare regime and the extent of reconciliation or 'family-friendly' policies such as the availability of parental leave, the right to flexible working arrangements, and the costs and coverage of childcare provision (Strandh and Nordenmark 2006; Van der Lippe et al. 2006; Gornick 2007). A recent special issue 
investigates the effect of policies on work-life balance from a theoretical/policy perspective (Gornick 2006). A forthcoming one considers the role of choice and constraint in achieving work-life balance in different contexts using a variety of approaches, mostly case studies (Gregory and Milner 2009).

The special issue edited by Janet Gornick uses a wide variety of comparative data sources and approaches. The European working conditions surveys (EWCS), conducted by the European foundation of working and living conditions provides excellent comparative evidence on the whole range of European countries (e.g., Thirion et al. 2007) but are not suited to exploring gender attitudes and arrangements in the domestic sphere, and the question on work-life conflict consists of a single item limited to working time. ${ }^{3}$

What does the ESS offer? The ESS is an academically-driven social survey designed to chart and explain the interaction between Europe's changing institutions and the attitudes, beliefs and behaviour patterns of its diverse populations. Its three main aims are to: produce rigorous data about people's underlying values within and between European nations; to rectify longstanding deficits in the rigour and equivalence of comparative quantitative research, especially in attitude surveys, and to develop and gain acceptance for social indicators, in addition to economic indicators of societal progress (Jowell et al. 2007). The survey covers over 30 countries and employs rigorous survey methodologies. ${ }^{4}$ The ESS is among the first social science projects to receive funding to support its infrastructure and in 2005 was awarded Europe's top annual science award, the Descartes prize 'for excellence in collaborative social research'.

The ESS special module on family, work and well-being (2004) was specifically designed to make possible an analysis of the impact of policy variation and the manner in which it affects work-family balance in a wide range of countries, in many of whom this topic has not been previously investigated. Questions in the special module cover topics such as work-family conflict and work-family spillover; work pressure, autonomy, pay and conditions of work; unpaid work, division of household labour and childcare. The data offers a unique opportunity to examine work-life conflict in Europe.

The specific work-life conflict indicators, used in a variety of papers, either in combination as a composite index or individually, are the following: 'How often do you keep worrying about work problems when you are not working?' 'How often do you feel too tired after work to enjoy the things you would like to do at home?' 'How often do you find that your job prevents you from giving the time you want to your partner or family?' and 'How often do you find that your partner or family gets fed up with the pressure of your job?' 5 These indicators are standard in the literature and widely used, though they do share with general work-life conflict debates a lack of clarity as to whether the issue at stake is work-life conflict, or work-family conflict, and whether life refers to caring or leisure or both (see MacInnes 2006 on this debate). This point is echoed by Pichler (2008), specifically referring to ESS data, when he argues that the work dimensions of work-life conflict in such indicators are more clearly conceptualised than the life indicators. More conceptual work may be needed on the meaning of 'life' in work-life conflict debates, in tandem with increased development of the 'life' indicators for survey research on work-life conflict. A

\footnotetext{
3 The question from the third and fourth working conditions surveys is: 'Do your working hours fit in with your family or social commitments outside work?'.

4 The fieldwork has been funded through the European Commission's fifth and sixth Framework Programme, the European Science Foundation and national funding bodies in each country.

5 A fifth question 'How often do you find it difficult to concentrate on work because of your family?' refers to family-to-work conflict, but is not used in any of the papers.
} 
linked critique is that the wordings of the work-life balance indicators lay too much emphasis on work as the probable explanation of work-life conflict or lack of time (Pichler 2008). However, the benefit of this wording is that the source of the problem is clearly identified. Other, more general formulations would offer considerably less clarity. ${ }^{6}$

European social survey response rates in general were high, with about half the countries achieving the target response rate of $70 \%$ (see appendix Table 1 for details). Great efforts were made in the ESS to ensure equivalence of questions across countries/ languages, which is crucial, given how sensitive attitudinal questions can be to question wording (Jowell et al. 2007).

The key strengths of the ESS are its cross-national representativeness and equivalence. It constitutes the outstanding source of data for European comparative research on worklife balance. Such data will never have the depth or nuance of qualitative studies, the detailed context of company case studies or of individuals' own accounts of balancing work and family life. Crucially the data is cross-sectional, so inferences about causality or conclusions about change over time are not possible. The articles in this volume seek to exploit the strengths of the ESS data.

\section{Overview of the Papers}

This special issue comprises papers covering a wide range of themes and approaches. The number of countries in each paper varies from 5 to 25: individual papers justify the selection of countries on the basis of their research question. Authors draw on a variety of different accounts of institutional and labour market variation, and a variety of theoretical perspectives. What the papers share is an overall comparative strategy which investigates the processes of interest and then asks do these differ across countries.

In the context of work intensification debates, Duncan Gallie and Helen Russell, in the first article in the volume, explore the influence of working conditions on work-life conflict in seven West European countries-Denmark, Norway, Sweden, Germany, The Netherlands, UK and France. They find that working conditions have a strong influence on the level of work-family conflict, measured as a composite index, in all seven countries. Work pressure has the most negative impact and the authors conclude that the marked rise in levels of work pressure in European countries since the early 1990s has contributed substantially to greater strain in managing work and family life. Rising skills levels in these countries may also have contributed, given that higher skill levels are associated with heightened work-life conflict.

Male employees in northern European societies display the lowest level of work-family conflict, a finding the authors attribute to shorter working hours and greater flexibility in assigning those hours. For female employees, no distinct pattern emerges and the authors argue that the origins of work-life conflict in the workplace may partly explain this. In the Scandanavian countries, where care/parental supports facilitate high employment among women, this is associated with longer working hours and higher levels of work pressure. In Britain and The Netherlands, family pressures are reduced due to the fact that many mothers work part-time.

\footnotetext{
${ }^{6}$ Another criticism is that work-life conflict is not well correlated with more general indicators of life satisfaction (Pichler 2008). Yet a number of studies find that work-life conflict measured in a rather different way, for example, as time stress, has a significant but modest association with work-life conflict (McGinnity and Russell 2007).
} 
Three papers address different debates in the work-life conflict literature. Nadia Steiber argues that it is useful to distinguish time-based and strain-based conflict, and uses the ESS indicators to do so in her contribution, which is based on 23 countries. She also distinguishes the impact of work demands, like long work hours, unpredictable work hours, evening/night/weekend work, from work resources like skill, time autonomy, job autonomy (control) and career prospects. The expectation is that work demands should exacerbate work-life conflict, while work resources will reduce it.

In general Steiber finds interesting gender differences in the factors associated with work-life conflict. Work demands such as long, unsocial and unpredictable working hours as well as work pressure increase work-life conflict, for both men and women. However, caring responsibilities increase time-based conflict for women only, while job insecurity increases strain-based conflict for men only. Using 23 countries allows Steiber to apply multi-level modelling to ESS data to formally model cross-country variation. Focusing on a sample of dual-earner couples, she finds that country effects are small. She thus concludes that the experience of work-family conflict appears to be only weakly moderated by institutional or cultural effects.

The next paper considers the supposition that work-life conflict is all part of a new West European culture of 'busyness' (e.g., Strandh and Nordenmark 2006). Drawing on debates from the time-use literature that busyness is a privileged position (Gershuny 2005) and that much time poverty is 'yuppie kvetch' or complaining (Hammermesh and Lee 2007), Frances McGinnity and Emma Calvert explore the relationship between worklife conflict and social inequality in eight West European countries: Germany, France, Spain, UK, Ireland, The Netherlands, Denmark and Sweden. To what extent is work-life conflict a problem of the rich and privileged professional classes, and is this true across countries?

The authors find higher work-life conflict among the professional classes in all eight countries. Some of this is explained by the fact that professionals work longer hours and experience more work pressure than other social classes, though the effect remains even after accounting for these factors. While levels of work-life conflict vary across the countries studied, country variation in class differences is modest, though class differences in work-life conflict are weakest in Sweden. The authors reflect on other explanations of why work-life conflict is higher among higher earners, and the policy implications of their findings, given recent European debates on why welfare states cannot afford to lose high-skilled female labour if they are to enhance competitiveness and reduce poverty.

As noted above, work-life conflict may in part be influenced by social comparison. In her paper, Katarina Boye uses ESS data to explore some more subjective elements of satisfaction in 25 countries. She examines whether social comparison affects the association between work and well-being, using the ESS to construct reference groups on the basis of country, sex and presence and age of children. The idea is that, for example, differences in hours of paid and unpaid work relative to key comparison groups may have an impact over and above absolute hours. She also explores the extent to which the relationship between hours and well-being varies between men and women, and the extent to which it is mediated by gender role attitudes.

In general she finds that while men's well-being appears to be unaffected by hours of paid work and housework, women's well-being increases with paid working hours and decreases with increased housework hours. Gender role attitudes do not appear to play a significant role in mediating the association between hours worked and well-being. However, within-country reference groups do appear to have some influence on women in 
relation to housework: compared to women in the same family situation, women who do less housework report higher well-being.

Two other papers focus on changing employment forms (temporary contract) and changing family forms (cohabitation) and their association with work-life conflict.

One changing form of employment which has received much attention in both academic and policy circles in Europe is temporary or fixed-term contracts (OECD 2002). Work has proliferated in recent years on the labour market and wage impact of these contracts, but much less is known about the 'social consequences' of fixed-term contracts, and their impact of quality of life. In her contribution, Stefani Scherer investigates the impact of having a fixed-term contract on the interface between work and family life in 16 West European countries. Scherer takes a broader view of the interface than simply work-life conflict, and outcomes investigated include fertility plans, job worries, life satisfaction, income worries and health problems, in addition to work-life conflict indicators.

The author finds that fixed-term contract employment is associated with negative effects for a range of social and family outcomes and these differences are partly but not fully explained by either working conditions or subjective job insecurity. The range of difficulties that arise include lower work satisfaction, lack of time for one's family, household income problems, family conflicts and child birth planning. Thus, Scherer argues, temporary contracts do not seem to facilitate the reconciliation of work and family life, but rather exacerbate levels of conflict, dissatisfaction and economic pressure. Overall, institutions such as the welfare state are important in shaping subjective indicators of individual and family life, though they only marginally affect the social consequences of non-stable employment.

A changing social form which has received particular attention in the US, to a much lesser extent in Europe, is cohabitation. Taking a selection of countries where cohabitation has a very different history and social significance, Kairi Kasearu considers whether worklife conflict differs between married and cohabiting couples and how this varies in five countries-Britain, Sweden, Germany, Estonia and Slovenia.

Work-life conflict, measured as a composite index, is somewhat lower for cohabiting men than married men, though there are no differences between married and cohabiting women. Kasearu finds that variation across couple type is completely explained by differences in socio-demographic characteristics, working conditions and attitudes. The exception is Sweden, where cohabiting women experience higher work-life conflict, even controlling for these factors, and the author considers why the Swedish case might be different. The key message is that cohabiting itself has no impact. The author suggests that cohabitation may be more similar to marriage in European than in the US.

The final two papers focus on wages and how they are related to work-family concerns. Vanessa Gash investigates how ongoing difficulties in work-family reconciliation result in inferior labour market outcomes for mothers, relative to women with no children. She finds mothers occupy an inferior market segment and earn a wage penalty in most of the six countries studied: Finland, Denmark, West Germany, France, The Netherlands, and The UK. Nonetheless, she finds strong institutional effects: in countries unsupportive of working motherhood, working mothers are more likely to occupy disadvantageous labour market positions relative to non-mothers, and incur a higher wage penalty. The United Kingdom and West Germany provide the least support for working mothers as 
well as the largest penalties to motherhood. Using ESS data, Gash explores two explanations for mothers' lower pay: that mothers trade wages for favourable, family-friendly working conditions and that they differ attitudinally from non-mothers, and that these 'attitudes' warrant less pay. She finds some evidence of mothers accepting lower paid jobs in Britain, a country with a high motherhood wage penalty, but no support for it in the other countries. She also finds no evidence that mothers differ attitudinally to nonmothers.

Javier Polavieja develops a rational action model of job allocation and explores its consequences for wages. He argues that the division of housework, job-specialisation requirements and imperfect information generate an incentive structure for individuals, which leads to gender differences in job allocation and wages. These incentives can be influenced by 'macro level' welfare policies and services, which may reduce the economic pay-offs of a traditional gender division of labour. Polavieja tests this model using ESS data on couples in 12 countries, fully exploiting the wide range of theoretically relevant variables on the dataset. The key finding is that gender differences in job specialisation and housework can explain the effect of occupational sex-composition on wages, even after accounting for gender differences in sex-role attitudes and personality traits.

The paper then investigates how incentive structures vary across welfare regime clusters: Polavieja finds that the association between housework and earnings is much weaker in societies with higher levels of decommodification (state/social policy allows independence from the market) and defamilization (state/social policy allows independence from the family), particularly the Scandanavian welfare cluster, to a lesser extent the postcommunist cluster.

The literature on work-life conflict is growing rapidly in volume and complexity. This collection of articles aims to contribute to these exciting developments on a number of fronts: by broadening the range of countries considered; by using a wide range of quantitative indicators associated with work-life conflict from an excellent, dedicated survey and by assessing the impact of the changing nature of work on the interface between work and life. The findings from this volume suggest that work-life conflict is more than just a fashionable term or a passing fad. It touches on core issues relating to the changing nature of work and the role it plays in people's lives. Viewing individuals as simply 'workers' is no longer an option for employers and governments. If EU governments are serious about achieving high employment economies without compromising fertility, i.e., the ability of those societies to reproduce themselves, work-life conflict is likely to stay on the agenda for many years to come.

Acknowledgments This special issue is the result of a collaborative research project among members of the Economic change, Quality of life and social cohesion (EQUALSOC) Network of excellence, funded by the European commission (DG research) as part of the sixth framework programme (www.equalsoc.org). The network has provided the opportunity and resources for the authors to meet on a regular basis to discuss underlying issues and comment upon each others work. The articles are all based on the European social survey (ESS), and we are very grateful to Roger Jowell and his colleagues for implementing and providing this excellent data source (www.europeansocialsurvey.org). We are also grateful to the 18 reviewers, whose insightful and critical comments have improved this volume immensely. Their names are listed in Appendix 2 in recognition of their contribution. Thanks also to Alex Michalos, the editor of Social Indicators Research, for his support of our project, and to Chiara Saraceno for the idea of compiling a special issue. Thanks too to Javier Polavieja, Nadia Steiber and Helen Russell for their comments on this introduction, and a special thanks to Emma Calvert for her enthusiastic assistance in putting the collection together. 


\section{Appendix 1}

See Table 1.

Table 1 ESS 2004 response rates by country

\begin{tabular}{lcl}
\hline Country & Achieved interviews & Response rate (\%) \\
\hline Austria & 2,256 & 62.4 \\
Belgium & 1,778 & 61.2 \\
Czech Republic & 3,026 & 55.3 \\
Denmark & 1,487 & 64.2 \\
Estonia & 1,989 & 79.1 \\
Finland & 2,022 & 70.7 \\
France & 1,806 & 43.6 \\
Germany & 2,870 & 51 \\
Greece & 2,406 & 78.8 \\
Hungary & 1,498 & 65.9 \\
Iceland & 579 & 51.3 \\
Ireland & 2,286 & 62.5 \\
Italy & 1,529 & 59.3 \\
Luxembourg & 1,635 & 50.1 \\
The Netherlands & 1,881 & 64.3 \\
Norway & 1,760 & 66.2 \\
Poland & 1,716 & 73.7 \\
Portugal & 2,052 & 71.2 \\
Slovakia & 1,512 & 62.7 \\
Slovenia & 1,442 & 70.2 \\
Spain & 1,663 & 54.9 \\
Sweden & 1,948 & 65.4 \\
Switzerland & 2,141 & 48.6 \\
Turkey & 1,856 & 50.7 \\
Ukraine & 2,031 & 66.6 \\
United Kingdom & 1,897 & 50.6 \\
\hline Souce: & &
\end{tabular}

Source $:$ http://ess.nsd.uib.no/index.jsp?year=2005\&module=fworksummary 


\section{Appendix 2: List of Reviewers}

Mick Cunningham, Western Washington University, Bellingham, WA, USA.

Shirley Dex, Institute of Education, London, England.

Jaap Dronkers, European University Institute, Florence, Italy.

Ann Zofie Duvander, Institute of Sociology, Stockholm University, Sweden.

Colette Fagan, University of Manchester, Manchester, England.

Tony Fahey, University College, Dublin, Ireland.

Duncan Gallie, Nuffield College, Oxford, England.

Jonathan Gershuny, University of Oxford, England.

Janet Gornick, Baruch College, City University of New York, New York, USA.

Steffen Hillmert, University of Tuebingen, Germany.

Kathleen Kiernan, University of York, York, England.

Richard Layte, Economic and Social Research Institute, Dublin, Ireland.

Patricia McManus, Indiana University, Bloomington IN, USA.

Magnus Nermo, Swedish Institute for Social Research, Stockholm, Sweden.

Philip O'Connell, Economic and Social Research Institute, Dublin, Ireland.

Michael Tahlin, Swedish Institute for Social Research, Stockholm, Sweden.

Tanja van der Lippe, Utrecht University, Utrecht, The Netherlands.

Claire Wallace, University of Aberdeen, Aberdeen, Scotland.

\section{References}

Allen, T., Herst, D., Bruck, C., \& Sutton, M. (2000). Consequences associated with work-to-family conflict: A review and agenda for future research. Journal of Occupational Health Psychology, 5, 278-308.

Bittman, M. (2004). Parenting and employment: What time-use surveys show. In N. Folbre \& M. Bittman (Eds.), Family time: The social organization of care. London: Routledge.

Bovenberg, A. L. (2007). The life-course perspective and social policies: An overview of the issues. Modernising Social Policy for the New Life Course, Paris: OECD.

Byron, K. (2005). A meta-analytic review of work-family conflict and its antecedents. Journal of Vocational Behavior, 67(2), 169-198.

Crompton, R., \& Lyonette, C. (2006). Work-life 'Balance' in Europe. Acta Sociologica, 49(4), 379-393.

Fagnani, J., \& Letablier, M. (2004). Work and family life balance: The impact of the 35-hour laws in France. Work, Employment \& Society, 18(3), 551-572.

Fahey, T., Nolan, B., \& Whelan, C. T. (2003). Monitoring quality of life in Europe. Dublin: European Foundation for the Improvement of Living and Working Conditions.

Felstead, A., Jewson, N., Phizacklea, A., \& Walters, S. (2002). Opportunities to work at home in the context of work-life balance. Human Resource Management Journal, 12(1), 54-76.

Ferrera, M., \& Rhodes, M. (2000). Recasting European welfare states: An introduction. Western European Politics, 23, 2-10.

Gershuny, J. (2000). Changing times. Work and leisure in post-industrial society. Oxford: Oxford University Press.

Gershuny, J. (2005). Busyness as the badge of honor for the new superordinate working class. Social Research: An International Quarterly of Social Sciences, 72(2), 287-314.

Gornick, J. (Ed.). (2006), Work family reconciliation policies: Theory and practice. Journal of Comparative Policy Analysis, 8(2), 201-114.

Gornick, J. (2007) Introduction in Does policy matter? The impact of work-family reconciliation policies on workers and their families. Special Issue of Journal of Comparative Policy Analysis, 9(2).

Gornick, J. C., \& Meyers, M. K. (2003). Families that work-Policies for reconciling parenthood and employment. New York: Russell Sage Foundation.

Greenhaus, J., Collins, K., \& Shaw, L. (2003). The relation between work-family balance and quality of life. Journal of Vocational Behavior, 63(3), 510-531. 
Greenhaus, J. H. \& Singh, R. (2003). Work-family linkages, a sloan work and family encyclopedia entry http://wfnetwork.bc.edu/encyclopedia_entry.php?id=263\&area=All.

Gregory, A. and Milner, S. (2009). Work-life balance: A matter of choice? Special Issue of Gender, Work and Organization 16(1).

Guest, D. (2002). Perspectives on the study of work-life balance. Social Science Information, 41(2), 255.

Hammermesh, D. S., \& Lee, J. (2007). Stressed out on four continents: Time crunch or yuppie kvetch? Review of Economics and Statistics, 89(2), 374-383.

Hildebrandt, E., \& Littig, B. (2006). Concepts, approaches and problems of work-life balance. European Societies, 8(2), 215-222.

Jacobs, J. A., \& Gerson, K. (2004). The time divide: Work. Family and Gender Inequality, Massachusetts: Harvard University Press.

Jowell, R., Roberts, C., Fitzgerald, R., \& Eva, G. (2007). Measuring attitudes cross-nationally: Lessons from the European social survey. London: Sage.

Kinnunen, U., Geurts, S., \& Mauno, S. (2004). Work-to-family conflict and its relationship with satisfaction and well-being: A one-year longitudinal study on gender differences. Work \& Stress, 18(1), 1-22.

Lewis, S., Gambles, R., \& Rapoport, S. (2007). The constraints of a 'work-life balance' approach: An international perspective. International Journal of Human Resource Management, 18(3), 360-373.

Lueck, D. (2006). The impact of gender role attitudes on women's life courses. In H. P. Blossfeld \& H. Hofmeister (Eds.), Globalization, uncertainty and women's careers: An international comparison. Cheltenham: Edward Elgar.

MacInnes, J. (2006). Work-life balance in Europe: A response to the baby bust or reward for the baby boomers? European Societies, 8(2), 223-249.

McGinnity, F., \& McManus, P. (2007). Paying the price for reconciling work and family life. Comparing the wage penalty for mother's part-time work in Britain, Germany and the United States. Journal of Comparative Policy Analysis, 9(2).

McGinnity, F., \& Russell, H. (2007). Work rich, time poor? Time use of men and women in Ireland. Economic and Social Review 38(3).

OECD. (2001). Balancing work and family life: Helping parents into paid employment (pp. 129-166). Paris: OECD Employment Outlook.

OECD. (2002). Taking the measure of temporary employment. Paris: Employment Outlook.

Perrons, D. (2003). The new economy and the work-life balance: Conceptual explorations and a case study of new media. Gender Work and Organization., 10(1), 65-93.

Pichler, F. (2008). Determinants of work-life balance: Shortcomings in the contemporary measurement of WLB in large-scale surveys. Social indicators research. doi: 10.1007/s11205-008-9297-5.

Scherer, S., \& Steiber, N. (2007). Work and family conflict? The impact of work demands on family life. In D. Gallie (Ed.), Employment regimes and the quality of working life. Oxford: Oxford University Press.

Schneider, B., \& Waite, L. J. (Eds.). (2005). Being together, working apart: Dual-career families and the work-life balance. Cambridge: CUP.

Steiber, N. (2007). The linkages between work and family: state of knowledge and policy implications. Equal soc policy paper (Vol. 2). Available from www.equalsoc.org.

Strandh, M., \& Nordenmark, N. (2006). The interference of paid work with household demands in different social policy contexts: Perceived work-household conflict in Sweden, UK, The Netherlands, Hungary, and The Czech Republic. The British Journal of Sociology, 57(4), 597-617.

Surender, R. (2004). Modern challenges to the welfare state and the antecedents of the third way. In J. Lewis \& R. Surender (Eds.), Welfare state change. Oxford: Oxford University Press.

Taylor-Gooby, P. (2004). New risks and social change. In P. Taylor-Gooby (Ed.), New risks, new welfare: The transformation of the European welfare state. Oxford: Oxford University Press.

Thirion, A., Macias, E., Hurley, J., \& Vermeylen, G. (2007). Fourth European working conditions survey. Luxembourg: Office for Official Publications of the European Communities.

Van der Lippe, T., Jager, A., \& Kops, Y. (2006). Combination pressure: The paid work-family balance of men and women in European countries. Acta Sociologica, 49(3), 303.

Veenhoven, R. (1996). Happy life-expectance: A comprehensive measure of quality-of-life in nations. Social Indicators Research, 39, 1-58.

Voydanoff, P. (2004). The effects of work demands and resources on work-to-family conflict and facilitation. Journal of Marriage and Family, 66(2), 398-412.

White, M., Hill, S., McGovern, P., Mills, C., \& Smeaton, D. (2003). "High-performance" management practices, working hours and work-life balance. British Journal of Industrial Relations, 41(2), 175-195. 